\title{
Not Known if EGFR Amplification Analysis Was Performed
}

National Cancer Institute

\section{Source}

National Cancer Institute. Not Known if EGFR Amplification Analysis Was Performed. NCI

Thesaurus. Code C160452.

An indication that it is not known whether EGFR amplification analysis was performed

during the study. 